\title{
Influence of Sugarcane Straw and Sowing DePTh on the EMERGence OF WeEd SPECIES ${ }^{1}$
}

\author{
A Influência da Palha de Cana-de-Açúcar e da Profundidade de Semeadura na Emergência de \\ Espécies Daninhas
}

SILVA, P.V. ${ }^{2}$, MONQUERO, P.A. ${ }^{2}$, SILVA, F.B. ${ }^{2}$, BEVILAQUA, N.C. ${ }^{2}$, and MALARDO, M.R. ${ }^{2}$

\begin{abstract}
This study aimed to understand the influence of sowing depth and the amount of sugarcane straw on the emergence of weed species Luffa aegyptiaca Miller (Cucurbitaceae); Mucuna aterrima Piper \& Tracy (Fabaceae - Leguminosae) and Ricinus communis (Euphorbiaceae). A completely randomized design with a $5 \times 4 \times 3$ factorial layout with four replications was used, at five sowing depths $(0,2,4,8$ and $10 \mathrm{~cm})$, four different amounts of sugarcane straw $\left(0,5,10\right.$ and $\left.15 \mathrm{t} \mathrm{ha}^{-1}\right)$ and three different evaluation periods $(7,14$ and 21 days after sowing). After sowing, different amounts of sugarcane straw $\left(0,5,10\right.$ and $\left.15 \mathrm{t} \mathrm{ha}^{-1}\right)$ were deposited on soil. Seedling emergence was analyzed at 7,14 and 21 days after sowing, counting the number of seedlings that had emerged. At the end of the trial, weed height $(\mathrm{cm})$, leaf area $\left(\mathrm{cm}^{2}\right)$ and shoot dry mass (g) were measured. In relation to emergence ability, studied species presented different responses according to sowing depth and to the amount of sugarcane straw deposited on the soil. For the L. aegyptiaca and M. aterrima, no significant difference was observed in the interaction between depth and sugarcane straw, showing the adaptation of these species to no-burn sugarcane system. For $R$. communis, seeds placed at $0 \mathrm{~cm}$ of sugar cane straw depth were observed to favor the emergence of seedlings.
\end{abstract}

Keywords: germination, no-burn sugarcane, mechanized harvesting.

\begin{abstract}
RESUMO - O objetivo deste trabalho foi estudar a influência da profundidade de semeadura e da quantidade de palha de cana-de-açúcar sobre a emergência das espécies daninhas Luffa aegyptiaca Miller (Cucurbitaceae), Mucuna aterrima Piper e Tracy (Fabaceae - Leguminosae) e Ricinus communis (Euphorbiaceae). O delineamento foi inteiramente casualizado, seguindo esquema fatorial $5 \times 4 \times 3$ com quatro repetições, sendo estudadas cinco profundidades de semeadura $(0,2,4,8$ e $10 \mathrm{~cm})$, quatro diferentes quantidades de palha de cana-de-açúcar $\left(0,5,10\right.$ e 15 tha $\left.^{-1}\right)$ e três periodos de avaliação $(7,14$ e 21 dias após a semeadura). Imediatamente após a semeadura, foram colocadas na superficie do solo as diferentes quantidades de palha $\left(0,5,10\right.$ e 15 tha $\left.^{-1}\right)$. A emergência das plântulas foi analisada aos 7, 14 e 21 dias após a semeadura, contando-se o número de plantas emergidas. Ao fim do ensaio, foram medidas a altura (cm), a área foliar $\left(\mathrm{cm}^{2}\right)$ e a massa seca da parte aérea das plantas daninhas (g). Em relação à capacidade de emergência, as espécies estudadas apresentaram diferentes respostas em função da profundidade de semeadura e da quantidade de palha depositada na superficie do solo. Para as espécies L. aegyptiaca $e$ M. aterrima, não se observaram diferenças significativas na interação entre as diferentes profundidades de semeadura e as quantidades de palha, o que demonstra adaptação dessas espécies ao sistema de cana crua. Já para $\boldsymbol{R}$. communis, notou-se que, no posicionamento das sementes a $0 \mathrm{~cm}$ de profundidade, a presença de palha favoreceu a emergência de plântulas.
\end{abstract}

Palavras-chave: germinação, cana crua, colheita mecanizada.

Recebido para publicação em 3.2.2015 e aprovado em 25.5.2015.

Universidade Federal de São Carlos, UFSCar, Araras-SP, Brasil, <paulovsi@yahoo.com.br>.

Planta Daninha, Viçosa-MG, v. 33, n. 3, p. 405-412, 2015 


\section{INTRODUCTION}

In mechanical harvesting, the straw left on the soil can be superior to $20 \mathrm{t} \mathrm{ha}^{-1}$ (Souza et al., 2005), representing a physical obstacle to seedling emergence and altering hydric and thermic balances. The amount and the quality of the light that reaches the soil's surface and also promotes the release of allelopathic compounds (Christoffoleti et al., 2007). The microenvironment created by the straw has stimulated seed germination and the development of some weed species (Correia \& Rezende, 2002), such as Ipomoea spp. and Merremia spp. (Azania et al., 2010), and recently Mucuna aterrima (Campos et al., 2011), Luffa aegyptiaca (Monquero et al., 2011; Zera et al., 2012) and Ricinus communis (Ramia et al., 2009). This alteration of the sugarcane's weeds can be related to some aspects of weed species characteristics seeds and with larger storage structure are able to overcome the straw layer deposited on the soil and their negative photoblastic behavior (Ruedell, 1995; Azania et al., 2002).

The presence of straw can also be related to the depth of the seeds in the soil, in which each species is able to germinate and produce seedlings (Kuva et al., 2007). The majority of the infesting plants have seeds with low storage material, being able to germinate only after being stimulated by the lighting stimulus in short depth soil. There are species, however, which do not need this stimulus and therefore have the ability to emerge in deeper soils due to the seeds possessing higher storage material (Canossa et al., 2007).

This aspect becomes extremely relevant as it shows how the straw addition on sugarcane production systems start to be a selective factor for weed seeds, making the establishment of some species difficult and for others a more favorable environment. The biology and control of weeds species that had their establishment facilitated in harvested sugarcane without previous burning still need to be elucidated. In this context, the knowledge about the dynamics of germination and emergence of seedlings from these species in different depths covered with sugarcane straw can represent an important tool for the adequate handling of weed species in sugarcane (Murdoch \& Carmona, 1993).

This study aimed to verify the emergence of the weed species Luffa aegyptiaca; Mucuna aterrima and Ricinus communis, when seeds were placed at different depths in the soil and covered with different amounts of sugar cane straw.

\section{MATERIALS AND METHODS}

Germination and emergence ability of weed species were studied in a completely randomized design with treatments disposed in a $5 \times 4 \times 3$ factorial layout. The first factor was sowing depth $(0,2,4,8$ and $10 \mathrm{~cm})$, followed by the amount of sugarcane straw $\left(0,5,10\right.$ and $\left.15 \mathrm{t} \mathrm{ha}^{-1}\right)$ and assessment period (7, 14 and 21 days after sowing). This design was carried out individually for each weed species (Luffa aegyptiaca, Mucuna aterrima and Ricinus communis), with four replications.

Experimental units were constituted by plastic pots with $3 \mathrm{~L}$ capacity, filled with sieved topsoil layer $(0-20 \mathrm{~cm})$ from clay dark oxisols. Soil samples were submitted to physical and chemical analyses, whose results are supplied in Table 1.

Sugarcane straw was obtained from commercial sugarcane fields in the Agriculture Science Center prior to herbicide application. The straw was air-dried, manually

Table 1 - Analyses of physical and chemical characteristics of the soil sample used in the experiment

\begin{tabular}{|c|c|c|c|c|c|c|c|c|c|c|c|c|}
\hline \multicolumn{10}{|c|}{ Red Latosol } \\
\hline $\mathrm{P}$ & $\mathrm{OM}$ & $\mathrm{pH}$ & $\mathrm{K}$ & $\mathrm{Ca}$ & $\mathrm{Mg}$ & $\mathrm{H}+\mathrm{Al}$ & $\mathrm{SB}$ & $\mathrm{CTC}$ & $\mathrm{V}$ & Clay & Sand & Silt \\
\hline$\left(\mathrm{mg} \mathrm{dm}^{-3}\right)$ & $\left(\mathrm{g} \mathrm{dm}^{-3}\right)$ & $\left(\mathrm{CaCl}_{2}\right)$ & \multicolumn{1}{|c|}{$\left(\mathrm{mmol}_{\mathrm{c}} \mathrm{dm}^{-3}\right)$} & & & $(\%)$ & & $\left(\mathrm{g} \mathrm{kg}^{-1}\right)$ & \\
\hline 26 & 25 & 5.1 & 4.2 & 32 & 15 & 21 & 51.4 & 72.4 & 71 & 560 & 240 & 200 \\
\hline
\end{tabular}

Source: Soil Chemistry and Fertility Laboratory of UFSCar (Federal University of Sao Carlos). 
chopped with the aid of scissors and stored in a dry place until the beginning of the experiment. In order to obtain the proportional amount of straw (in kilograms per hectare) to be distributed on the surface of the pots, a simple cross multiplication was carried out taking the area of experimental units into account.

Before sowing, $M$. aterrima seeds were treated to break their dormancy, according to Trani et al. (1991). Seeds from all species were also treated with the fungicide tetramethylthiuram disulfide (250 g a.i. per $100 \mathrm{~kg}$ of seeds). The pots were marked with white dye from the surface using a ruler to distribute the seeds at different depths $(0,2$, 4,8 and $10 \mathrm{~cm}$ ). At $0 \mathrm{~cm}$ depth, seeds were homogeneously placed on the soil. After the procedure, the soil surface was homogenized and pressed with equal force to standardize the depths and improve the contact between seed and soil. Immediately after sowing, the required amount of sugarcane straw was placed on the soil surface to promote the expected densities according to the experimental design. To constitute 5,10 and $15 \mathrm{tha}^{-1}$ of straw, $7.30 \mathrm{~g}$, $34.6 \mathrm{~g}$ and $51.9 \mathrm{~g}$ were used, respectively.

The amounts of seeds used to obtain 10 seedlings were 12 seeds for Luffa aegyptiaca and 13 seeds for both Mucuna aterrima and Ricinus communis.. The pots were placed in a greenhouse with $10 \mathrm{~mm}$ irrigation per day. The emergence of seedlings was analyzed at 7,14 and 21 days after sowing (DAS), counting the number of seedlings at each time for each treatment, and counting only those that presented cotyledonary leaves.

The data obtained was transformed to percentages considering the total number of seeds placed in each pot. At 21 DAS the height (cm) was obtained, measuring the plant from the soil until apical meristem of the main stem. The leaf area measurements were carried out at 21 DAS using a non-destructive method by means of the Licor-3100 device. Also at 21 DAS the plants were cut close to the soil, seeds placed in each pot in paper bags and dried at $60{ }^{\circ} \mathrm{C}$ in a forced air oven until reaching a constant weight in order to obtain the dry matter of the plants. The data obtained for each species was submitted to analysis of variance (ANOVA) using the F-test with means compared by the Tukey Test at 5\% significance using the statistical program ASSISTAT. The emergence results were analyzed by ANOVA according to a factorial layout. For the height, leaf area, and dry matter parameters, the data were analyzed individually because all evaluations occurred at the same time.

\section{RESULTS AND DISCUSSION}

Analyzing the interaction between sowing depth and the amount of straw on the soil surface (Table 2), emergence of $L$. aegyptiaca seedlings was observed for all treatments. This interaction, however, did not present significant differences, showing that the interaction between sowing depth $(0,2,4,8$ and $10 \mathrm{~cm}$ ) and the amount of straw present in the soil surface did not affect the emergence of this species.

These data are similar to the results obtained from Masson et al. (2010) who reported that the $L$. aegyptiaca species emerged at $14 \mathrm{~cm}$ depth $(6.0 \mathrm{~cm}$ of soil and $7.0 \mathrm{~cm}$ of straw) with seedlings developing in similar conditions to those harvested from sugar cane fields in the no-burn sugarcane system. These results show the greater adaptation of this species to the tillage method used.

Although the interaction between sowing depth and the amount of straw was not significant, plant vigor (measured from dry matter, height and leaf area) presented variation. For aerial dry matter at a sowing depth of $10 \mathrm{~cm}$, lower dry matter production was observed for treatments with 0 and $5 \mathrm{t} \mathrm{ha}^{-1}$ of straw (Table 3). No significant difference was observed for sowing depth. For seed position at $10 \mathrm{~cm}$ depth, though, higher dry matter values of $L$. aegyptiaca seedlings were observed as the amount of straw deposited on the soil surface increased.

For leaf area, the interaction between sowing depth and amount of straw produced significantly different results. Analyzing the data from Table 3, it was observed that the treatment at $0 \mathrm{~cm}$ with $0 \mathrm{t} \mathrm{ha}^{-1}$ of straw on the soil surface affected L. aegyptiaca seedling development, resulting in a foliage area of $11.56 \mathrm{~cm}^{2}$, the lowest value for the treatments studied. Using $10 \mathrm{t} \mathrm{ha}^{-1}$ of straw, the only 
Table 2 - Percentage of emergence of Luffa aegyptiaca for the interaction of different sowing depths and the amount of sugar cane straw deposited on the soil

\begin{tabular}{|c|c|c|c|c|c|c|c|c|}
\hline \multicolumn{9}{|c|}{ Amount of straw $\left(\mathrm{t} \mathrm{ha}^{-1}\right)$} \\
\hline \multirow{2}{*}{ Depth (cm) } & \multicolumn{2}{|c|}{0} & \multicolumn{2}{|c|}{5} & \multicolumn{2}{|c|}{10} & \multicolumn{2}{|c|}{15} \\
\hline & Orig. & Transf. & Orig. & Transf. & Orig. & Transf. & Orig. & Transf \\
\hline 0 & 25.51 & 26.46 & 29.92 & 32.18 & 30.67 & 32.67 & 31.43 & 33.69 \\
\hline 2 & 26.86 & 29.46 & 29.98 & 32.46 & 36.35 & 35.34 & 36.35 & 36.47 \\
\hline 4 & 30.67 & 32.25 & 29.16 & 30.50 & 37.18 & 36.79 & 27.64 & 29.77 \\
\hline 8 & 26.51 & 27.53 & 31.43 & 30.68 & 33.28 & 33.95 & 27.26 & 27.60 \\
\hline 10 & 31.05 & 31.10 & 30.29 & 28.21 & 28.93 & 28.71 & 28.00 & 28.59 \\
\hline \multicolumn{3}{|c|}{$F_{(d e p t h)}=2.87 *$} & \multicolumn{4}{|c|}{$\mathrm{F}_{(\text {straw })}=3.50 *$} & \multicolumn{2}{|c|}{$\mathrm{F}_{(\text {depth } \mathrm{x} \text { straw })=\mathrm{nS}}$} \\
\hline \multicolumn{9}{|c|}{ CV (\%) 22.70} \\
\hline
\end{tabular}

Orig: original data; Transf: transformed data by $\operatorname{arc}$ sine $(x / 100)$; ns (non-significant); * (significant at a level of $5 \%$ probability by $\mathrm{F}$ Test); CV (coefficient of variation).

Table 3 - Shoot dry mass, foliage area and plant height of Luffa aegyptica at 21 DAS according to different sowing depths and amounts of straw deposited on the soil surface

\begin{tabular}{|c|c|c|c|c|}
\hline \multirow{3}{*}{$\begin{array}{l}\text { Depth } \\
\text { (cm) }\end{array}$} & \multicolumn{4}{|c|}{ Amount of straw $\left(\mathrm{t} \mathrm{ha}^{-1}\right)$} \\
\hline & \multicolumn{4}{|c|}{ Shoot dry mass (g) } \\
\hline & 0 & 5 & 10 & 15 \\
\hline 0 & $0.10 \mathrm{aA}$ & $0.20 \mathrm{aA}$ & $0.19 \mathrm{aA}$ & $0.17 \mathrm{aA}$ \\
\hline 2 & $0.21 \mathrm{aA}$ & $0.20 \mathrm{aA}$ & $0.19 \mathrm{aA}$ & $0.19 \mathrm{aA}$ \\
\hline 4 & $0.17 \mathrm{aA}$ & $0.18 \mathrm{aA}$ & $0.21 \mathrm{aA}$ & $0.18 \mathrm{aA}$ \\
\hline 8 & $0.18 \mathrm{aA}$ & $0.22 \mathrm{aA}$ & $0.23 \mathrm{aA}$ & $0.19 \mathrm{aA}$ \\
\hline 10 & $0.15 \mathrm{aB}$ & $0.14 \mathrm{aB}$ & $0.26 \mathrm{aA}$ & $0.19 \mathrm{aA}$ \\
\hline \multicolumn{2}{|c|}{$\mathrm{F}_{(\mathrm{depth})}=1.54 *$} & \multicolumn{2}{|c|}{$\mathrm{F}_{\text {(straw) }}=3.44^{*}$} & $\mathrm{~F}_{\text {(depth } \mathrm{x} \text { straw) }}=1.05^{*}$ \\
\hline \multicolumn{3}{|c|}{$\mathrm{DMS}_{(\mathrm{depth})}=0.05$} & \multicolumn{2}{|c|}{ DMS $_{\text {(straw) }}=0.06$} \\
\hline \multicolumn{5}{|c|}{ CV(\%) 25.92} \\
\hline & \multicolumn{4}{|c|}{ Leaf area $\left(\mathrm{cm}^{2}\right)$} \\
\hline 0 & $11.56 \mathrm{aB}$ & $20.44 \mathrm{aA}$ & $18.62 \mathrm{aA}$ & $20.61 \mathrm{aA}$ \\
\hline 2 & $16.61 \mathrm{aA}$ & $14.13 \mathrm{aA}$ & $10.93 \mathrm{bA}$ & $15.65 \mathrm{aA}$ \\
\hline 4 & $15.35 \mathrm{aA}$ & $20.20 \mathrm{aA}$ & $18.27 \mathrm{abA}$ & $14.48 \mathrm{aA}$ \\
\hline 8 & $17.84 \mathrm{aA}$ & $19.09 \mathrm{aA}$ & $18.33 \mathrm{abA}$ & $18.38 \mathrm{aA}$ \\
\hline 10 & $18.61 \mathrm{aA}$ & $16.06 \mathrm{aA}$ & $15.13 \mathrm{abA}$ & $18.59 \mathrm{aA}$ \\
\hline \multicolumn{2}{|c|}{$\mathrm{F}_{(\mathrm{depth})}=2.82 *$} & \multicolumn{2}{|l|}{$\mathrm{F}_{\text {(straw) }}=\mathrm{ns}$} & (depth $x$ straw) $=2.16^{*}$ \\
\hline \multicolumn{3}{|c|}{ DMS $_{(\text {depth) }}=6.96$} & \multicolumn{2}{|c|}{ DMS $_{\text {(straw) }}=7.40$} \\
\hline \multicolumn{5}{|c|}{ CV $(\%) 21.97$} \\
\hline & \multicolumn{4}{|c|}{ Height $(\mathrm{cm})$} \\
\hline 0 & $4.20 \mathrm{aB}$ & 7.05 bcA & $7.63 \mathrm{bcA}$ & $7.95 \mathrm{abA}$ \\
\hline 2 & $5.82 \mathrm{abB}$ & $5.94 \mathrm{cB}$ & $5.28 \mathrm{cA}$ & $9.20 \mathrm{aA}$ \\
\hline 4 & $5.26 \mathrm{abA}$ & 6.95 bcA & $9.08 \mathrm{abA}$ & $6.55 \mathrm{bA}$ \\
\hline 8 & $7.29 \mathrm{aA}$ & $9.63 \mathrm{aA}$ & 7.64 bcA & 8.92 abA \\
\hline 10 & $6.22 \mathrm{abB}$ & $8.36 \mathrm{abAB}$ & $10.06 \mathrm{aA}$ & $8.07 \mathrm{abAB}$ \\
\hline \multicolumn{2}{|c|}{$\mathrm{F}_{(\mathrm{depth})}=10.26^{* *}$} & $\mathrm{~F}_{(\text {straw) }}=15.3 \mathrm{~s}$ & \multicolumn{2}{|c|}{$\mathrm{F}_{(\mathrm{depth}} \mathrm{x}$ straw) $=3.23^{* *}$} \\
\hline \multicolumn{3}{|c|}{ DMS $_{(\text {depth }}=1.23$} & \multicolumn{2}{|c|}{$\mathrm{DMS}_{\text {(straw) }}=1.03$} \\
\hline \multicolumn{5}{|c|}{ CV (\%) 16.87} \\
\hline
\end{tabular}

* (significant at a level of $5 \%$ probability by F-test); ** (significant at a level of $1 \%$ probability by F-test); CV (coefficient of variation); MSD (minimal significant difference). Means followed by different lowercase letter in the column and uppercase letters in the rows are significantly different by the Tukey test at $5 \%$ significance. significant reduction of leaf area occurred when the seeds were at $2 \mathrm{~cm}$ depth, resulting in $10.93 \mathrm{~cm}^{2}$ of leaf area. The other treatments did not differ significantly.

Similar results were obtained by Correia et al. (2012), who studied the influence of sowing depth and the amount of sugarcane straw on the emergence of Rottboellia exaltata. The authors reported lower dry matter accumulation when the seeds were distributed on the surface of the soil. This lower development at the most superficial sowing and without straw was justified by the higher difficulty of root system development.

In relation to plant height (Table 3 ), the addition of straw resulted in taller, but more etiolated plants at the most superficial seed placements $(0$ and $2 \mathrm{~cm})$. At $10 \mathrm{~cm}$ of depth and with $10 \mathrm{t} \mathrm{ha}^{-1}$ of straw the seedlings presented an increased height $(10.06 \mathrm{~cm})$. On the other hand, seeds placed at the surface and with no straw resulted in seedlings with less height $(4.20 \mathrm{~cm})$. From the presented results, an adaptation of Luffa aegyptica to the no-burn sugarcane harvest system and consequent straw deposition on the soil surface were observed.

For the species Mucuna aterima, an interaction between seed position and amount of straw did not present a statistical difference (Table 4), with seedling emergence occurring in all treatments. Similar results by Silva et al. (2013) showed that this species was indifferent to the presence or absence of straw, which was 
Table 4 - Percentage of Mucuna aterrima in emergence based on the interaction between different sowing depths and the amount of sugar cane straw deposited on the soil surface

\begin{tabular}{|c|c|c|c|c|c|c|c|c|}
\hline \multicolumn{9}{|c|}{ Amount of straw $\left(\mathrm{t} \mathrm{ha}^{-1}\right)$} \\
\hline \multirow{2}{*}{ Depth $(\mathrm{cm})$} & \multicolumn{2}{|c|}{0} & \multicolumn{2}{|c|}{5} & \multicolumn{2}{|c|}{10} & \multicolumn{2}{|c|}{15} \\
\hline & Orig. & Transf. & Orig. & Transf. & Orig. & Transf. & Orig. & Transf. \\
\hline 0 & 38.43 & 32.94 & 35.88 & 31.51 & 30.12 & 28.13 & 37.81 & 32.63 \\
\hline 2 & 37.43 & 32.23 & 28.83 & 27.39 & 23.07 & 23.33 & 24.35 & 24.45 \\
\hline 4 & 30.75 & 28.47 & 35.24 & 31.10 & 37.16 & 32.22 & 34.60 & 30.75 \\
\hline 8 & 36.53 & 31.89 & 30.10 & 27.81 & 32.30 & 29.34 & 28.77 & 27.36 \\
\hline 10 & 15.36 & 18.52 & 16.02 & 19.36 & 17.94 & 20.63 & 15.32 & 19.02 \\
\hline \multirow{2}{*}{\multicolumn{3}{|c|}{$\mathrm{F}_{\text {(depth) }}=26,43^{* *}$}} & \multicolumn{4}{|c|}{$\mathrm{F}_{(\text {straw })}=\mathrm{ns}$} & \multicolumn{2}{|c|}{$\mathrm{F}_{\text {(depth } \mathrm{x} \text { straw) }}=\mathrm{ns}$} \\
\hline & & & \multicolumn{6}{|c|}{ CV (\%) 23.68} \\
\hline
\end{tabular}

Orig. original data; Transf: transformed data by $\operatorname{arc}$ sine $(x / 100)$; ns (non-significant); ** (significant at level of $1 \%$ probability by F-test); CV (coefficient of variation).

a condition that was also observed in the present study because the plants were able to overcome $10 \mathrm{~cm}$ of soil plus $15 \mathrm{t} \mathrm{ha}^{-1}$ of straw.

Campos et al. (2011) also did not observe a significant interaction between the effects of sowing depth and sugarcane straw cover, highlighting that this species is highly adapted to no-burn sugarcane harvest. Silva et al. (2013) observed that $M$. aterrima presented their highest emergence when the seeds were near the soil surface and with no straw, but also observed that this species was able to overcome $23 \mathrm{t} \mathrm{ha}^{-1}$ of straw and up to $8 \mathrm{~cm}$ of sowing depth.

At 21 DAS (Table 5), the absence of straw and a high sowing depth $(8$ and $10 \mathrm{~cm})$ resulted in the increase of dry matter values. At soil densities of 5,10 and $15 \mathrm{t} \mathrm{ha}^{-1}$ no statistical difference was observed between sowing depths. For seed position at 8 and $10 \mathrm{~cm}$, the increase in straw amount to $15 \mathrm{t} \mathrm{ha}^{-1}$ resulted in a decrease of dry matter value. Yamauti et al. (2011) observed that seed placement under sugarcane straw resulted in a higher dry matter value when compared to treatments where sowing was on or between the straw in a study about the emergence of Mucuna cinerum, showing higher adaptation of this species to a no-burn sugarcane system. In this study, it was also observed that a straw amount of $8 \mathrm{tha}^{-1}$ resulted in a higher value of dry matter.

Silva et al. (2013) did not find effects of sowing depth on the dry matter content of
Table 5 - Shoot dry mass, leaf area and height of Mucuna aterrima seedlings at 21 DAS, according to different sowing depths and the amount of straw deposited on the soil surface

\begin{tabular}{|c|c|c|c|c|}
\hline & \multicolumn{4}{|c|}{ Amount of straw $\left(\mathrm{t} \mathrm{ha}^{-1}\right)$} \\
\hline $\begin{array}{l}\text { Depth } \\
\text { (cm) }\end{array}$ & \multicolumn{4}{|c|}{ Shoot dry mass (g) } \\
\hline & 0 & 5 & 10 & 15 \\
\hline 0 & $6.21 \mathrm{bA}$ & $5.01 \mathrm{aA}$ & $4.27 \mathrm{aA}$ & $5.70 \mathrm{aA}$ \\
\hline 2 & $5.18 \mathrm{bA}$ & $4.18 \mathrm{aA}$ & $6.06 \mathrm{aA}$ & $3.80 \mathrm{aA}$ \\
\hline 4 & $6.56 \mathrm{bA}$ & $8.05 \mathrm{aA}$ & $8.59 \mathrm{aA}$ & $4.97 \mathrm{aA}$ \\
\hline 8 & $11.72 \mathrm{aA}$ & $4.45 \mathrm{aB}$ & $8.28 \mathrm{aAB}$ & $7.60 \mathrm{aB}$ \\
\hline 10 & 8.58 abA & 5.80 aAB & $6.16 \mathrm{aAB}$ & $4.28 \mathrm{aB}$ \\
\hline \multicolumn{3}{|c|}{$\mathrm{F}_{(\mathrm{dep} t \mathrm{t})}=5.63 * *$} & \multicolumn{2}{|c|}{$\mathrm{F}_{(\text {depth } \mathrm{x} \text { straw } \mathrm{x} \text { period) }}=2.18$} \\
\hline \multicolumn{3}{|c|}{ DMS $_{\text {(depth } \mathrm{x} \text { straw) }}=4.34$} & \multicolumn{2}{|c|}{ DMS $_{\text {(period) }}=4.08$} \\
\hline \multicolumn{5}{|c|}{ CV (\%) 29.78} \\
\hline & \multicolumn{4}{|c|}{ Leaf area $\left(\mathrm{cm}^{2}\right)$} \\
\hline 0 & 206.39 & 195.44 & 195.90 & 200.21 \\
\hline 2 & 205.04 & 271.47 & 239.81 & 185.26 \\
\hline 4 & 228.82 & 199.96 & 188.24 & 183.27 \\
\hline 8 & 237.17 & 192.00 & 155.15 & 165.43 \\
\hline 10 & 276.98 & 262.75 & 211.00 & 214.84 \\
\hline \multicolumn{2}{|c|}{$F_{\text {(depth) }}=3.30 *$} & \multicolumn{2}{|c|}{$F_{(\text {straw })}=3.81 *$} & straw) $=\mathrm{ns}$ \\
\hline \multicolumn{5}{|c|}{ CV (\%) 19.68} \\
\hline & \multicolumn{4}{|c|}{ Height $(\mathrm{cm})$} \\
\hline 0 & 60.47 & 51.24 & 55.61 & 58.51 \\
\hline 2 & 59.16 & 51.42 & 62.03 & 48.65 \\
\hline 4 & 74.44 & 72.68 & 68.12 & 67.08 \\
\hline 8 & 88.41 & 69.75 & 59.52 & 67.04 \\
\hline 10 & 69.41 & 65.00 & 71.63 & 66.50 \\
\hline \multicolumn{2}{|c|}{$\mathrm{F}(\mathrm{depth})=4.70 *$} & \multicolumn{2}{|c|}{$\mathrm{F}_{\text {(straw) }}=\mathrm{ns}$} & straw $)=n$ \\
\hline & & CV $(\%) 1$ & & \\
\hline
\end{tabular}

ns (non-significant); * (significant at a level of $5 \%$ probability by F-test); ** (significant at a level of $1 \%$ probability by F-test); CV (coefficient of variation); MSD (minimal significant difference). Means followed by different lowercase letters in the column and uppercase letters in the rows significantly differ by the Tukey test at $5 \%$ significance.

Planta Daninha, Viçosa-MG, v. 33, n. 3, p. 405-412, 2015 
$M$. aterrima but observed that the lower value of dry matter was obtained when no straw was used, and that treatments with higher amounts of straw (9 and $23 \mathrm{t} \mathrm{ha}^{-1}$ ) were statistically equal. These results show a positive effect of sugarcane straw on the development of this species.

For the leaf area obtained (Table 5), the interaction between sowing depth and the amount of straw was not observed to produce significantly different results. Silva et al. (2013) found that for foliage area, the interaction with sowing depth did not present a statistical difference, however the deposition of straw on the soil surface was significant and higher amounts of this coverage ( 9 and $23 \mathrm{t} \mathrm{ha}^{-1}$ ) resulted in seedlings with higher photosynthetic areas.

For the variable height, the interaction of depth and straw factors did not produce statistical differences (Table 5). Yamauti et al. (2011) found that as the seeds were placed deeper, the height of seedlings became greater, and that the use of more straw resulted in more etiolated $M$. cinereum seedlings, with depositions of 8 and $16 \mathrm{t} \mathrm{ha}^{-1}$ presenting higher values for this variable.

In relation to the $R$. communis species, the interaction between depth and straw was significant. At $0 \mathrm{~cm}$ of sowing depth, the presence of straw resulted in an increase in the number of seedlings. Among the treatments studied, it was observed that superficial sowing $(0 \mathrm{~cm})$ with no straw resulted in lower emergence of this species $(34.51 \%)$, showing that straw presence on the soil surface can favor its development, predominantly when the seed is exposed. In all other treatments, the emergence percentage was higher than $40 \%$, highlighting the adaptation capacity of this species in noburn sugarcane areas (Table 6).

Distinct results were obtained by Masson et al. (2010), who studied R. communis emergence under different sowing depths (0.5; 2.0; 4.0 and $6.0 \mathrm{~cm}$ ) and at a deposition of $16 \mathrm{t} \mathrm{ha}^{-1}$ of sugarcane straw and found out that the emergence of this species was highest at a seed placement of $0.5 \mathrm{~cm}$ depth and that the number of seedlings gradually decreased as sowing depth increased. It is however
Table 6 - Percentage of Ricinus communis emergence according to the interaction of different sowing depths and amounts of sugarcane straw deposited on the soil surface

\begin{tabular}{|c|c|c|c|c|}
\hline \multicolumn{5}{|c|}{ Amount of straw $\left(\mathrm{t} \mathrm{ha}^{-1}\right)$} \\
\hline $\begin{array}{c}\text { Depth } \\
\text { (cm) }\end{array}$ & 0 & 5 & 10 & 15 \\
\hline 0 & $35.41 \mathrm{bB}$ & $47.91 \mathrm{abA}$ & $45.83 \mathrm{aA}$ & $50.83 \mathrm{aA}$ \\
\hline 2 & $48.75 \mathrm{aA}$ & $50.00 \mathrm{abA}$ & 43.75 aA & $49.16 \mathrm{abA}$ \\
\hline 4 & $46.66 \mathrm{aA}$ & $53.75 \mathrm{aA}$ & $49.16 \mathrm{aA}$ & $51.66 \mathrm{aA}$ \\
\hline 8 & $44.16 \mathrm{aA}$ & $47.91 \mathrm{abA}$ & $47.50 \mathrm{aA}$ & $45.00 \mathrm{abA}$ \\
\hline 10 & $46.25 \mathrm{aA}$ & $43.75 \mathrm{bA}$ & $49.16 \mathrm{aA}$ & $41.25 \mathrm{bA}$ \\
\hline \multicolumn{5}{|c|}{$\mathrm{F}_{(\mathrm{depth})}=4.04 * *$} \\
\hline \multicolumn{2}{|c|}{$\mathrm{DMS}_{(\mathrm{depth)})}=8.17$} & & \multicolumn{2}{|c|}{$\mathrm{DMS}_{(\text {straw) }}=8.68$} \\
\hline \multicolumn{5}{|c|}{ CV (\%)16.4 } \\
\hline
\end{tabular}

* (significant at a level of $5 \%$ probability by F-test); ** (significantly at a level of $1 \%$ probability by $\mathrm{F}$ test); CV (coefficient of variation); MSD (minimal significantly difference). Means followed by different lowercase letters in the column and uppercase letters in the rows significantly differ by the Tukey test at $5 \%$ significance.

noteworthy that at $6.0 \mathrm{~cm}$ of sowing depth, some seedlings were obtained.

Shoot dry mass of $R$. communis did not present a statistical difference (Table 7). Masson et al. (2010) found that $R$. communis is favored by the increase of straw, with better development obtained for this species up to $2 \mathrm{~cm}$ depth, in which seedlings can overcome $2 \mathrm{~cm}$ of soil and $7 \mathrm{~cm}$ of straw $\left(16 \mathrm{t} \mathrm{ha}^{-1}\right)$. At sowing depths of 4 and $6 \mathrm{~cm}$, it was however observed that the seedlings had some difficulty in overcoming soil and straw barriers, which affected their establishment.

For leaf area, statistical difference was observed among the treatments. For seedlings from seeds placed at 0 or $4 \mathrm{~cm}$ soil depth, the presence of straw was a factor that promoted larger leaf area. Upon the addition of sugarcane straw, higher values were observed when no straw was used and at the amount of $15 \mathrm{t} \mathrm{ha}^{-1}$ of straw, with seeds placed at $2 \mathrm{~cm}$ of soil depth (Table 7). The data analysis of leaf area showed that although the emergence of $R$. communis did not present significant differences according to sowing depth and amount of straw, the seedling vigor varied. At the most superficial depth $(0 \mathrm{~cm})$ with no straw, less developed seedlings were obtained, which were therefore more vulnerable to changes in weather.

Similar behavior was also observed when height was analyzed; when sowing 
Table 7 - Shoot dry mass, leaf area and height of seedlings of Ricinus communis at 21 DAS according to different sowing depths and amount of straw deposited on the soil surface

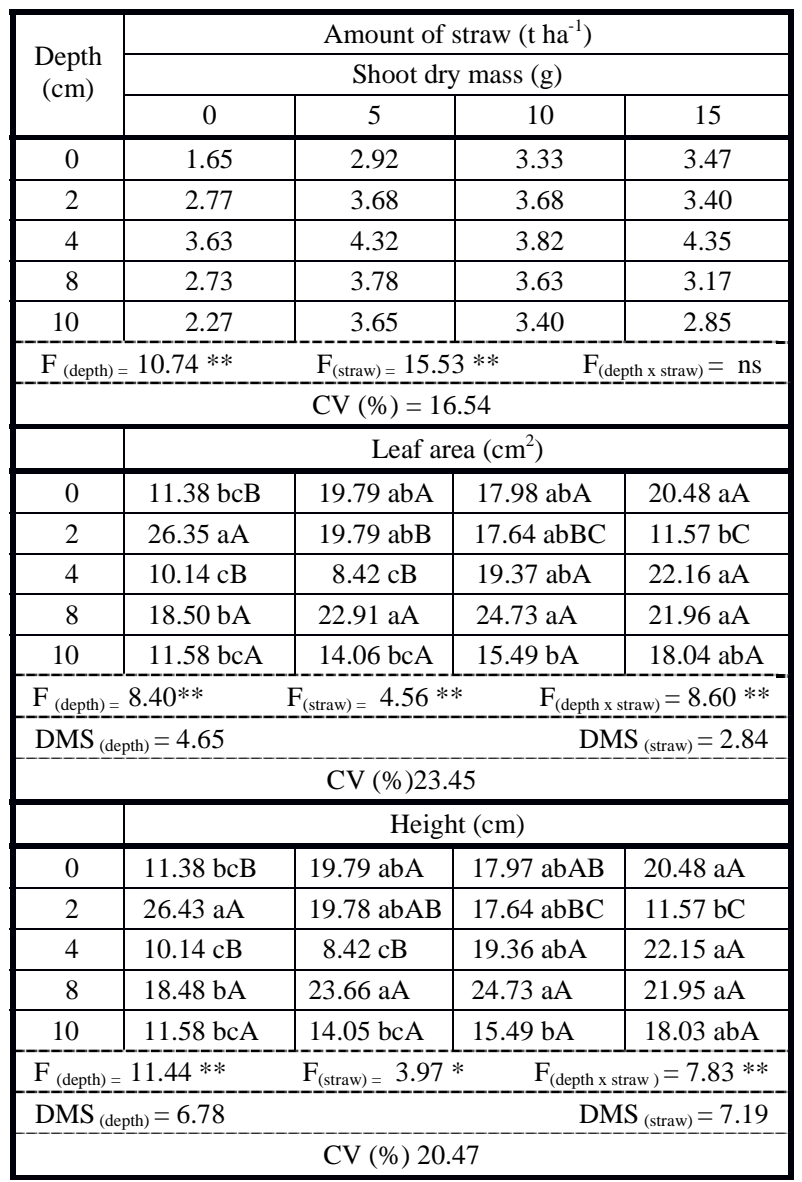

* (significant at a level of $5 \%$ probability by F-test ** (significant at a level of $1 \%$ probability by F-test); CV (coefficient of variation); MSD (minimal significant difference). Means followed by different lowercase letters in the column and uppercase letters in the rows significantly differ by the Tukey test at $5 \%$ significance.

R. communis at 0 and $4 \mathrm{~cm}$ of depth, the increase in the amount of straw on the soil surface was observed to result in more etiolated plants; for seeds placed at $2 \mathrm{~cm}$ of depth, the increase in the amount of straw decreased the height of this species. For treatments at 8 and $10 \mathrm{~cm}$ of depth, no significant height difference was observed for the amount of straw on the soil surface.

These data are similar to the results obtained by Masson et al. (2010) which involved a lower height of $R$. communis observed when seeds were placed at $6 \mathrm{~cm}$ of depth. The authors also reported that castor beans overcame $6 \mathrm{~cm}$ of soil layer and $7 \mathrm{~cm}$ of straw in the germination process, and their seedlings developed satisfactorily.

All R. communis treatments produced seedlings, however their vigor presented variation. The most superficial sowing with no straw presented lower emergence and affected the development of seedlings. Sowing depths of 4 and $8 \mathrm{~cm}$ promoted the highest number of seedlings and the deeper sowing $(10 \mathrm{~cm})$ presented obstacles for the emergence of this species.

These results are in agreement with the theory that weed species present different behaviors in the presence of sugarcane straw, in which the latter can favor the initial establishment of some species while simultaneously can act suppressing other species. In the case of L. aegyptiaca, $R$. communis and $M$. aterrima, the presence of straw on soil favored their development and initial establishment. According to Lorenzi (1994), this behavior is justified by the large seed size of these weed species, which allows them to develop satisfactorily at great depths in the soil with different amounts of sugarcane straw on the soils.

According to Theisen \& Vidal (1999), these weed species can overcome straw barriers when germinating and can establish on sugarcane fields where they exert their interference. When the soils is protected with straw, the plants that survive the initial establishment difficulties are normally benefited by a low population, which provides them a greater portion of environment resources, favoring their development and seed production, and providing aggressive competition to sugarcane.

The species studied presented adaptation to the mechanical harvesting system of sugarcane, and consequently to straw deposition on the soil surface. This behavior is probably associated to some characteristics relating to the biology of these weed species, such as their seed size, which are large and present a considerable storage structure contributing to $L$. aegyptiaca, $R$. communis and $M$. aterrima seedlings to overcome significant sowing depths and straw densities without damaging their development. 
From the results presented, it was observed that sowing depth and the amount of straw cannot affect Luffa aegyptiaca and Mucuna aterrima emergence; however they have direct influence on their vigor. For Ricinus communis, the interaction between sowing depth and different amounts of straw was found to not only affect the emergence of castor beans but also the initial establishment of the seedlings that have emerged. $R$. communis had its emergence favored when seeds were placed on the surface and in all treatments the emergence percentage was greater than $40 \%$. These results show the adaptation of these species to raw sugarcane.

\section{LITERATURE CITED}

AZANIA, A. A. P. M. et al. Interferência da palha de cana-deaçúcar (Saccharum spp.) na emergência de espécies de plantas daninhas da família Convolvulaceae. Planta Daninha, v. 20, n. 2, p.207-212, 2002.

AZANIA, C. A. M. et al. Eficácia de herbicidas no controle de espécies de corda-de-viola em cana-de-açúcar. STAB, v. 29, p. 41-45, 2010.

CAMPOS, L. H. F. et al. Emergência de Merremi acissoides, Mucuna aterrima e Neonotonia wightii sob diferentes profundidades de semeadura e quantidades de palha de canade-açúcar. Planta Daninha, v. 29, p. 975-980, 2011. (Número Especial)

CANOSSA, R. S. et al. Profundidade de semeadura afetando a emergência de plântulas de Alternanthera tenella.

Planta Daninha, v. 25, n. 4, p. 719-725, 2007.

CHRISTOFFOLETI, P. J. et al. Conservation of natural resources in Brazilian agriculture: implications on weed biology and management. Crop Protec., v. 26, n. 3, p. 383-389, 2007.

CORREIA, N. M.; PERUSSI, F. J.; GOMES, L. J. P. Emergência de Rottboellia exaltata influenciada pela quantidade de palha de cana sobre o solo e aplicação de herbicidas residuais. In: CONGRESSO BRASILEIRO DA CIÊNCIA DAS PLANTAS DANINHAS, 28., 2012, Campo Grande. Palestras... Campo Grande: 2012. p. 27-32.

CORREIA, N. M.; REZENDE, P. M. Manejo integrado de plantas daninhas na cultura da soja. Lavras: UFLA, 2002. 55 p. (Boletim Agropecuário, 51).

LORENZI, H. Plantas daninhas do Brasil. 4.ed. Nova Odessa: Plantarum, 1994. 440 p.
KUVA, M.; PITELLI, R. A.; SALGADO, T. P. Fitossociologia de comunidades de plantas daninhas em agroecossistema cana-crua. Planta Daninha, v. 25, n. 3, p. 501-511, 2007.

MASSON, J. et al. Emergência de plantas daninhas sob diferentes profundidades de semeadura e palha de cana-deaçúcar. In: CONGRESSO BRASILEIRO DA CIÊNCIA DAS PLANTAS DANINHAS, 2010, Ribeirão Preto. Anais... Ribeirão Preto: Congresso Brasileiro da Ciência das Plantas Daninhas, 2010.

MONQUERO, P. A.; DALLA COSTA, V.; KROWOSLOSKI, V. Saflufenacil no controle de Luffa aegyptiaca, Merremia cissoides, Mucuna aterrima e Ricinus communis. R. Bras. Herbic., v. 10, n. 3, p. 176-182, 2011.

MURDOCH, A. J.; CARMONA, R. The implications of the annual dormancy cycle of buried weed seeds for novel methods of weed control. In: BRIGHTON CROP PROTECTION CONFERENCE - WEEDS, 1993, Brighton. Proceedings... Brighton: British Crop Protection Association, 1993. p. 329-334.

RAMIA, V. V. et al . Manejo químico de Ricinus communis utilizando herbicidas seletivos à cana-de-açúcar. STAB, v. 28, n. 1, p. 38-41, 2009.

RUEDELL, J. Plantio direto na região de Cruz Alta. Cruz Alta: FUNDACEP FECOTRIGO, 1995. 134 p.

SILVA, G. B. et al. Superação da profundidade de semeadura e densidades de palha para Mucuna aterrima, Mucuna deeringiana e Mucuna cinerea. Planta Daninha, v. 31, n. 2, p. 313-317, 2013.

SOUZA, Z. M. et al. Sistemas de colheita e manejo da palhada de cana-de-açúcar. Pesq. Agropec. Bras., v. 40, n. 3, p. 271-278, 2005.

THEISEN, G.; VIDAL, R. A. Efeito da cobertura do solo com resíduos de aveia-preta nas etapas do ciclo de vida do capim marmelada. Planta Daninha, v. 17, n. 3, p. 189-196, 1999.

TRANI, P. E.; BULISANI, E. A.; BRAGA, N. R. Adubação verde. Campinas: CATI/CECOR, 1991. (Boletim Técnico)

YAMAUTI, M. S. et al. Emergência de plantas daninhas em função da posição da semente e quantidade de palha de canade-açúcar. Sci. Agr., v. 12, n. 1, p. 75-80, 2011.

ZERA, F. S. et al. Tolerância de Luffa aegyptiaca a herbicidas utilizados em cana-de-açúcar. STAB, v. 30, n. 1, p. 50-52, 2012. 